\title{
Literary tourism as a promoter of cultural heritage
}

\author{
L. Ghetau \& L. V. Esanu \\ Faculty of Geography and Geology, Iasi University, Romania
}

\begin{abstract}
In the recent past, Government interest toward conserving and promoting Romanian cultural heritage has visibly increased. National authorities are trying to uphold it as a single entity through different measures like cultural events and touristic activities.

The drawback to this otherwise positive course of action is that this process cannot oversee or offer an efficient degree of protection and an even exposure to all types of cultural objectives. None the less, promoting cultural heritage holds top priority, but at the same time it is equally important that there are no hasty measures taken and an appropriate exposure of all its facets is granted.

A more fitting solution for accomplishing the task at hand would be to first divide Romania's cultural objectives in distinct groups, in this case literature, and attach a suitable form of tourism dedicated to its requirements. In order to meet these terms a series of conditions must be taken into consideration.

Literature's relationship with tourism has already been consecrated through Literary Tourism, but this marriage of worlds has yet to be described from a geographical perspective. In order to validate this point of view Romania's literary icons have been brought up because of their crucial role in shaping the country's image and people.

This study would be responsible of drawing attention to a new form of tourism for Romania; one which focuses on promoting aspects and personalities form the literary world.

Working with specialised forms of tourism represents a mature and efficient approach toward the sustainable promotion of a destination's cultural heritage. Keywords: cultural heritage, literary icons, tourism, conservation, sustainability.
\end{abstract}




\section{Introduction}

Writing and travel have represented one of the greatest hobbies of civilized man, the two playing an important role in shaping and defining ones intellect by first broadening his horizon of the World.

Even though their original purpose has not yet been fully elucidated, somewhere along the way, literature and travel have common purposes; both answering man's need to escape the daily routine of life. It is impossible for one who discovers literature or travel not to come across the other at some point in his journey.

Through free will and most of all through imagination the two were joined together forming what is known today as literary tourism. A fusion of two worlds, seemingly so far apart but at the same time so close to each other, acting as an extension of man's understating process regarding not only himself but also what surrounds him.

Literary tourism originated in the United Kingdom making its presence felt around the second part of the eighteenth century and well into the early beginning of the nineteenth century when it started to be seen as a very popular form of travel for the youth of that time.

Throughout time the phenomenon spread quite rapidly to other parts of Europe and even to Russia and the United States of America capturing the attention not only of enthusiast readers of all ages, but also of the academic world.

Scholars like Stephen Coan, Mike Robinson, Randy Malamud or Nicola J. Watson all rose to the challenge and over time elaborated numerous scientific articles and books regarding the importance or validity of literary tourism. And as with any other phenomenon that increases its popularity it started to attract both positive and negative feedback, some considering it to be the next step in the bonding process between a reader and the author's work while critics look at this form of travel as being a cheap appropriation.

Although the opinions regarding literary tourism's utility are divided, one quality must not be overlooked; it's potential for conservation and proper promotion of literary icons along with their associated destinations, aspects which overlap with the main task of the current paper.

Literature is a form of spiritual travel, while tourism is the ink with which it is written.

Using a geographical point of view the body text shall contain several chapters dedicated to properly placing this form of travel within the general context of the touristic phenomenon and to demonstrate its utility in the conservation process of a destination's cultural heritage by introducing it to a location which shows affinity toward literary tourism.

For this study the earlier mentioned perspective is crucial because until this moment the subject of literary tourism has been discussed mainly from a sociological, literary or economic angle leaving aside the factor of spatiality.

Not taking into consideration the final factor leaves this form of travel suspended to some degree, because without a proper understanding of its spatial 
patterns its purpose is only half uncovered. In the present situation geography does not act as another individual element brought into discussion, but rather as a bonding agent.

One author, Stephen Coan, raises the subject of literature's spatial dimension and how it can influence tourism, in his book 'Read book, will travel', but the subject is not appropriately addressed from beginning to end lacking a geographer's perspective.

Another problem, but at a general level, regards the perception of literary tourism as two separate components in a relation where one influences the other, thus steering attention away from the more pressing issue of conserving cultural heritage. The joining of two or more terms does not always create a situation where one rises above the rest. Literary tourism represents an exception where its origins complement each other, even though the name that defines this activity is composed.

This apparently odd match of words represents their affiliation to the unconventional touristic practices, a frequent characteristic among alternative forms of travel.

\section{Theoretical framework}

The purpose of an alternative form of travel is mainly to serve as an answer to the specific conservational needs of a particular category of objective that can be found within the ensemble of a destination's cultural heritage, representing an active instrument in any plan for sustainable development strategy.

Understanding the semantics of the words used in naming these instruments and the meaning that results after their fusion symbolizes one of the essential first steps towards constructing an interdisciplinary theoretical background from which further progress can be made. Because of its quite fascinating and at the same time natural word association, literary tourism represents a topic that can also be placed within the same class of forms of travel like, dark tourism, urban questing or industrial archaeology; all drawing their names from the activities around which they revolve.

The role of elaborating the name's meaning is that it grants the opportunity of uncovering which are the scientific domains that can be implicated in the study and would best serve it.

With literary tourism the aspect of deciphering its name was somewhat overlooked, studies concerning the current subject being focused mainly on sociological aspects. This approach is reflected in various works, like The Literary Tourist, Read book, will travel or The Value of Literary Tourism. Upon an inspection of their general structure on can observe a series of similarities concerning the phenomenon's analysis; pinpointing the exact destination of origin, the time of its birth, types of objectives, tourists that fall under this category and also the motivation behind their journey.

Even though different authors have complied a personalised portrait of the literary tourist and his destination of choice; one stands out in particular. In his work Read book, will travel Stephen Coan provides a very straight forward 
distinction between the different types of visitors which show varied degrees of affinity toward this form o travel.

The researcher mentions in his studies two distinct types of literary tourist, representing the extremities of this typology; in the first category he distinguishes the literary pilgrim - being represented by the avid admirers and at the opposite part of his description there are those who choose to integrate into their vacation itinerary a destination related to what they have read in the past [1].

Based on this first distinction the author went on and elaborated his vision regarding the literary tourist, establishing what in particular motivates the target group to partake in this form of travel. From his studies Coan distinguishes that practitioners of literary tourism are drawn by all literary aspects concerning the text, author and even movie scripts [1].

Although the book brings to light very important issues concerning literary tourism's inner workings at the same time it limits itself at uncovering what is the tourist's role is in this equation; thus proving its focus on a precise area of expertise, sociology.

This attention toward a single perspective leaves numerous questions unanswered, some of them regarding crucial aspects like the spatial dimension of this phenomenon, where does it lie in the world of tourism or if it is capable of bringing socio-economical benefits.

It is true that sociology lies at the heart of every situation where the human element is implicated but without analysing the pattern through which it spreads or by not giving an equal priority to any of the earlier questions, a study on tourism based on a solitary scientific perspective is destined to walk through the dark.

Human geography brings a crucial element to studies on tourism, a sense of direction, which is not only done through written depiction, but also and most importantly through cartographical support; being represented by different types of specially designed maps which can embody a variety of aspects ranging from pinpointing the location of objectives to illustrating the migration pattern of visitors to and from the location of interest. These aspects coupled with the social viewpoint are able to reach out and correctly address queries as those above.

The element of orientation provided by human geography, in this case, adds a considerable degree of precision and depth to the understanding process; usually definitions are able to sum up perfectly the different areas of expertise through which a subject has been approached.

In a 2009 issue of The Chronicle of Higher Education, Randy Malamud provides a brief but favourable argument in which he states that literary tourism travel with a focus on historical locales connected to famous authors [2]. This short description can also serve as a definition for this alternative form of travel, from which it can be clearly seen that Malamud shares a similar perspective as Stephen Coan; both creating an image that partially taps the subject.

A more complex definition, but still within the same lines as the previous examples has been provided by an online magazine called The Heart of New 
England which considers that literary tourism is a type of cultural tourism to places related to events or fictional characters in books. It also involves visiting places and areas related to the lives of the book authors [3].

As before, the current definition elucidates very important characteristics which none the less make up literary tourism's trademark, but at the same time it lacks a certain degree of precision and wholeness.

Definitions can be seen as a summary for an entire theoretical framework which in several lines must be able to describe the main characteristics of a phenomenon but also address issues concerning placement within a vaster area of study and also a clear purpose.

Taking into consideration the examples provided by the previous paragraphs along with a more composite approach, literary tourism represents a form of travel which resides under the category of alternative types of tourism, representing an instrument designed for the conservational purposes of a specific category of cultural heritage; in the current case objectives, locations, events related to different aspects of literature. Also, adding to the creation or consolidation of an area's cultural identity and playing a decisive role in its quest for sustainable development.

The earlier definition serves as a multidisciplinary insight which manages to capture literary tourism's implication in the socio-economical scene and not just to present types of objectives or sites that are characteristic for this form of travel.

Alternative forms of tourism, like literary tourism, represent the prime instruments responsible with the sustainable development of an area's cultural identity and preservation of its cultural heritage.

Literary tourism's role increases exponentially when it comes to its implementation in a new area because it becomes one of the first steps taken by local authorities in the ongoing process of raising the community's awareness regarding the importance of cultural heritage and their slow economical reorientation.

\section{Iasi - a cultural destination}

Changing the economic profile of an urban environment can pose quite a challenging task even for the most experienced planners. The process requiring a well formulated vision based on the city's remaining assets and also the full support of its local community.

The urban environments most likely to undergo this transformation are those which were once renowned for their economic profile based mainly on industrial activities.

Western European cities like those of the United Kingdom have become models of efficiency through their capacity to transform former industrial icons as Liverpool, Leeds or Salford into veritable cultural destinations.

Over time these examples have inspired other cities, which come from a similar background, to adopt similar initiatives based on sustainable 
development principles in order to guarantee a bright future for their younger generation.

An urban environment which is currently undergoing this slow process of economic reorientation is the city of Iasi, Romania. During the socialist regime Iasi was known nationally as one of the many greatly industrialized urban environments. But after 1989 these activities were abandoned because of the costly upkeep.

The following time interval was spent by local officials assessing the alterations brought, by the forced insertion of industrial activities, to the urban landscape.

Through the aid of its universities, different organizations like the Iasi 600 Foundation and the combined initiatives commenced by local authorities the city has been able to successfully promote its diverse types of cultural objectives (e.g. museums, churches, historical buildings etc.).

In order to encourage the practice of different forms of cultural tourism annually various events are organised, each being dedicated to a distinct artistic sphere. Until now Iasi been the host of events such as the Cucteni 5000 Fair (promoting the traditional craft of pot making), the Doc Est Film Festival and Zilele Ludicului (a theatrical performance festival); all drawing annually important touristic flows.

Literature and all related aspects also represent an important element in Iasi's cultural heritage. Even though this fact has been upheld through different small events, like Copou - parcul poeziei, Scriitori pe calea regală, Zidurile care vorbesc or Tramvaiul cu scriitori; they still lack the necessary visibility to impose a distinct shade and attract more significant flows of literary enthusiasts.

Insuring that Iasi's literary sphere is taken to a higher level of promotion without compromising its authenticity in favour of a short term lucrative strategy, a new form of management is required; represented through an instrument capable of balancing both aspects.

The situation can be solved through a long term insertion plan of an alternative form of touristic management, literary tourism.

By placing all events and cultural objectives, related to literature, underneath one identity then it creates a coherent facet which boosts the overall cultural image of the city.

Diversifying and sustaining literary related activities in Iasi could represent a perfect opportunity to draw attention on existing monuments, memorial houses; representing the last direct link to many national educational breakthroughs.

Within the city's urban limits numerous literary historical landmarks can be found, many of which have stood the test of time only to be slowly wiped away from the public's memory.

Out of the wide variety of objectives seven have been chosen in order to highlight through a brief description their decisive influence that they've had on the country's history and culture.

The Dosoftei Memorial House was built by Dosoftei in the second half of the 17th century; after the construction process was finalized the owner installed the second printing press in all of Modova. Here he printed the following religious 
books: Liturghia (1679), Psaltirea de-nţeles (1680), Viaţa şi petrecerea sfinţilor (1682-1686).

Between the years 1966 - 1969 the building was renovated and in 1970 it served as an extension for the Museum of Romanian Literature hosting the Old Literature display, keeping safe in its cases several important artefacts like a Slavic manuscript dating back from the $14^{\text {th }}$ century, a Liturghier which was printed by Macarie in the year 1508 (the first ever Romanian printed document) and also a life-size replica of Dosoftei's printing press and many other religious paintings which date back from the 16 th and 18th century [4].

The Mihail Sadoveanu Memorial House was originally built by Mihail Kogălniceanu in the year 1842 with craftsmen brought over from Italy. In 1867 because of financial problems Kogalniceanu was forced to sell the building. After 51 years the house was bought by Mihail Sadoveanu and his brother. Before moving to Bucharest in 1936 the famous author will have written here over 35 books, period which proved to be his most prosperous; leaving behind masterpieces such as: Hanul Ancutei (1928), Zodia Cancerului (1929), Baltagul (1930) and many others. After Sadoveanu left for Bucharest the famous Romanian musician George Enescu lived in the beautiful home for about two years. And in 1980 the building was declared the Mihail Sadoveanu Museum, also serving as the headquarters for the Institute of linguistics, literary history and folklore which belonged to the Academy and Institute for Anthropology [4].

The Gheorghe Asachi Memorial House, the building can be found in place of the 'Asachi School'; here took place the first seminars on Romanian language. A famous sculptor from Bucharest called Gheorghe Lazar sculpted a statue in his honour which can be found today in front of the National Theatre [4].

The Vasile Pogor Memorial House was built in 1850 by Vasile Pogor, property which was later given to his son Vasile V. Pogor (publicist, poet, mayor of Iaşi and one of the five founding fathers of the Junimena Society). The building was also called the 'the house with bright windows' because it was one of the first houses in Iaşi to have electricity.

'The house with bright windows' served as a meeting place for the members of the Junimea Society [4].

The Ion Creangă Memorial House. Ion Creangă lived as an underlessor for the Vartic family. The house was located in a modest part of the town. In 1879 Ion Creangă bought the house form the Vartic family and decorated it to suit his needs as an author.

As homage to Creangă's contribution to literature in 1918 his home became Romania's first Memorial Museum [4].

The Otilia Cazimir Memorial House. It was bought in 1908 by Gheorghe Gavrilescu, Alexandra Gavrilescu's (the future Otilia Cazimir) father. She remained in this house, until her final days on Earth, greeting friends like: George Topirceanu, Mihai Codreanu, Petre Comarnescu, George Lesnea, Nicolae Labis, Florin Mihai Petrescu, Ion Istrati, Ana Maslea.

On the 10th of June 1972 the house was declared a museum; visitors who cross its threshold can still find personal belongings which were found in the late author's possession [4]. 
The Mihail Codreanu Memorial House. The plot of land was give to the author in 1933 by the city council as a reward for all his activity as a writer and citizen. The house called 'Vila Sonet' was finished in 1934 in accordance to the owner's specifications. The famous writer lived here until the $23^{\text {rd }}$ of October 1957 when he died. After his death the house served as a haven for authors who often dropped by for a glass of wine and a game of chess. Some of these visitors were famous authors like: Mihail Sadoveanu, George Topîrceanu, Ionel Teodoreanu, Demostene Botez, Otilia Cazimir. Because of their frequent visits the 'Villa Sonet' became known throughout the country as being the meeting place for all of Romania's bohemian society, numerous literary debates being held there.

Today the 'Vila Sonet' and all the late authors' possessions are being guarded by the two bronze bulldogs placed at the house's entrance [5].

Another factor for which these specific objectives were chosen was their spatial positioning and arrangement within the city's urban boundaries.

This does not only represent an advantage when organising the itinerary of a guided tour but the objectives can be seen as a source for the redenomination of neighbouring businesses and attraction of potential investments.

By attracting visitors to the proposed locations, business owners could benefit from this impulse and slowly adapt their economic activities to match with the objective's theme.

Understanding the importance of matching the surrounding area to the objective's topic helps raze the degree of emotional impact on visitors, also prolonging the feeling of authenticity.

Encouraging this type of spatial accord would not only enforce a truly sustainable area within the city but would also set the foundation for a project where the entire urban area could be divided based on the type of touristic objectives found within their proximity.

Thus by managing touristic objectives through a specialised form of tourism, such as literary tourism, would guarantee that they are well conserved and represent a significant asset in consolidating Iasi's plan for a social, economical and cultural sustainable development.

\section{Summary}

Understanding the necessity of sustainable development and implementing specific strategies represents a crucial course of action that must to be adopted by local authorities when an urban environment is passing through a process of socio-economical reorientation.

Cities like Iasi which are still looking to consolidate their external image as cultural destinations must look toward alternative forms of tourism in order to obtain an even exposure for each type of objective.

Benefiting from a rich history Iasi will be able to incorporate literary tourism into its already growing ensemble of alternative forms of tourism, taking it closer to the standards of sustainability set by other international cultural destinations. 
Pre-existing cultural events, like Tramvaiul cu scriitori, dedicated to celebrating past and contemporary literary icons demonstrates that the city's affinity and preoccupation toward keeping its traditions alive is still present.

For this study case the insertion of literary tourism as a symbol of touristic management would grant local officials the possibility of discovering more efficient methods of conservation and exposure through international partnerships with other cultural destinations which have shown determination and progress in identifying themselves through alternative forms of travel.

By adopting a 'divide et impera' approach along with a well formulated long term development strategy Iasi shall be able to consolidate its image among other already existing cultural destinations.

\section{References}

[1] Read book, will travel by Stephen Coan http://www.literarytourism.co.za/index.php?option=com_content\& task $=$ view $\&$ id $=85 \&$ Itemid $=42$

[2] The Value of Literary Tourism by Jennifer M. Eisenlau http://www.transitionsabroad.com/listings/study/articles/study-abroad-thevalue-of-literary-tourism.shtml

[3] Online magazine The Heart of New England http://www.theheartofnewengland.com/travel/nh/literary-tourism.html

[4] Romanian Memorial Houses http://museum.ici.ro/moldova/Iași/romanian/fmuzeu.htm

[5] 2005, Plan de amenajare a teritoriului metropolitan Iaşi, S.C. HABITAT PROIECT S.A., Iaşi 